\title{
Dissecting Aneurysm of the Aorta due to Giant Cell Arteritis
}

\author{
M. HARRIS \\ From the Department of Pathology, University of Bristol
}

Giant cell arteritis is a rare cause of dissecting aneurysm. Nine examples have been hitherto reported, and in this paper 2 new cases are recorded.

Review of 77 examples of dissecting aneurysm in the necropsy records of this department has failed to reveal any further cases attributable to giant cell arteritis. Shennan (1934) and Sailer (1942) who reviewed 300 and approximately 500 necropsies, respectively, of patients with dissecting aneurysm, did not describe any with lesions resembling giant cell arteritis, though they did refer to a small number in which there was syphilitic or rheumatic aortitis. In Manley's series of 27 dissecting aneurysms (Manley, 1962), there were 2 cases of giant cell aortitis, one with coexisting cystic medionecrosis. Harrison (1948), in his review of 75 patients with giant cell arteritis, including 12 necropsies, found 9 in which the aorta was involved, but none where dissecting aneurysm had occurred.

\section{CASE REPORTS}

Case 1. A woman, aged 70 years, was admitted to hospital after suddenly losing consciousness while travelling on a bus. She had been quite well earlier in the day, and there was no history suggesting temporal arteritis. She was comatose and responded only to strong stimuli. Her blood pressure was $150 / 110 \mathrm{~mm}$. $\mathrm{Hg}$, and later it fell to $75 / 40 \mathrm{~mm}$. $\mathrm{Hg}$. The pulses of her right arm were not palpable but both femoral pulses and the left radial pulse were normal. There was a loud systolic murmur over the whole praecordium and over the right carotid artery. The total white cell count was 10,400 per cu.mm. (polymorphs 9100) and the ESR was $55 \mathrm{~mm}$. in 1 hour (Wintrobe).

She died the next day without regaining consciousness.

Necropsy. A dissecting aneurysm was present in the ascending aorta and the aortic arch, extending into the

Received March 1, 1968 innominate artery and the right subclavian and carotid arteries. The left common carotid artery was involved, but the left subclavian artery was spared. Proximally the aneurysm had burst into the pericardial sac which contained $300 \mathrm{ml}$. of blood. $2.5 \mathrm{~cm}$. above the aortic valve ring there was a transverse intimal tear $(7 \cdot 5 \mathrm{~cm}$. long) which almost encircled the aorta.

The heart weighed $420 \mathrm{~g}$. and the left ventricle was hypertrophied. There was a small recent infarct in the right occipito-parietal region of the brain. The thyroid weighed only 10 g., and its cut surface was pale and fibrous.

There were no other relevant findings.

Histology. The temporal arteries were not examined, but both lingual arteries and the right and left coronary arteries showed typical active giant cell arteritis (Fig. 1). In all sections the tunica intima was greatly thickened by proliferation of fibroblasts and formation of delicate collagen fibres; capillary blood vessels lined by plump endothelial cells were present in the periphery of the thickened intima. The tunica media and tunica adventitia were infiltrated by lymphocytes, plasma cells, and histiocytes, and multinucleated giant cells were present along the outer aspect of the fragmented internal elastic lamina. In the right coronary artery the internal elastic lamina was extremely fragmented and represented only by occasional coarse, deeply basophilic strands of degenerate elastic fibre, resembling those described by Heptinstall, Porter, and Barkley (1954) (Fig. 2).

Sections from the ascending aorta, aortic arch, and descending aorta all showed extensive irregular areas where the tunica media was infiltrated by plasma cells, lymphocytes, histiocytes, and a few multinucleated giant cells of foreign body type. In these zones there was some necrosis of muscle fibres and marked fragmentation and loss of elastic fibres (Fig. 3 and 4). The changes were most prominent in the outer half of the media but not infrequently involved its full thickness. Staining with toluidine blue showed only a slight increase in metachromatic ground substance. There was no metachromasia in the inflamed regions and no "cyst" forma840 


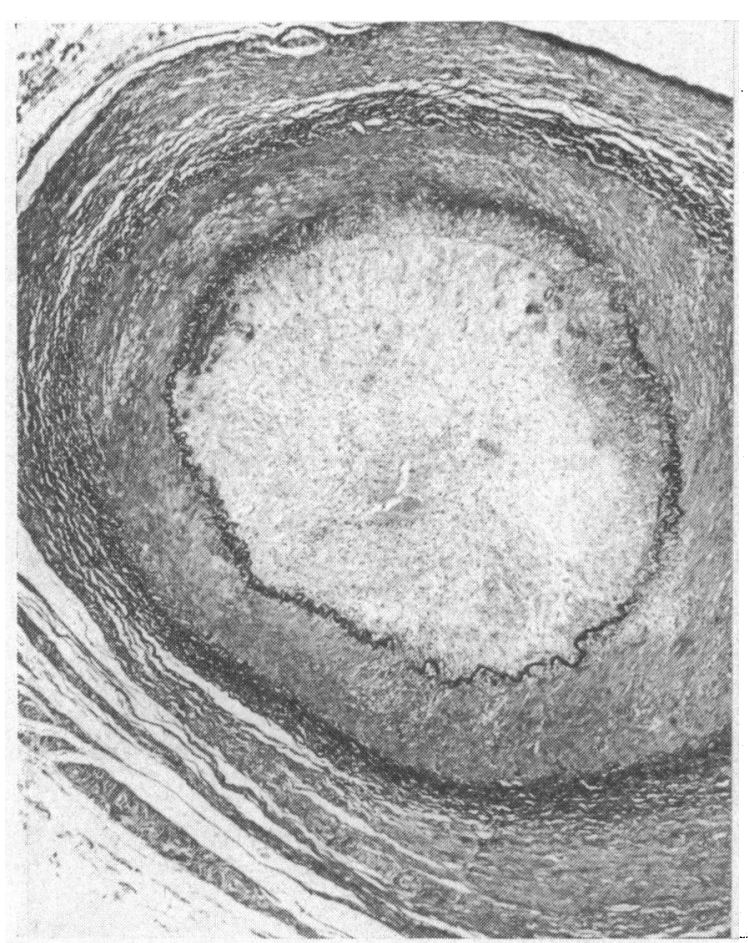

Fig. 1.-Case 1. Lingual artery showing marked intimal thickening, fragmentation of the internal elastic lamina, and chronic inflammatory cells infiltrating the media. (Elastic van Gieson. $\times 29$.)

cyte and plasma cell infiltration, sometimes perivascular, but endarteritis of the vasa vasorum was not present.

Both common carotid arteries showed similar inflammatory changes, with loss of elastic fibres and occasional zones of slight intimal thickening.

Sections of the kidney showed hypertensive arteriolosclerosis. In the thyroid there was extensive fibrosis, with atrophy of glandular tissue. There was no arteritis within the gland, and the main thyroid arteries were not examined.

Case 2. In 1965 the patient, a woman aged 81 years, developed tonsillitis which was treated with penicillin. One week later she complained of severe headaches, and painful temporal arteries were noticed. After a further week she lost sensation in her mouth, tongue, and throat, and was admitted to hospital where she was found to have tender, swollen temporal arteries. The lower twothirds of her face was cold and cyanosed, her tongue was purple, and there was extensive discoloration of her scalp. Her blood pressure was $140 / 100 \mathrm{~mm}$. Hg. The total white cell count was 22,000 per cu.mm. (92\% polymorphs) and the ESR was $46 \mathrm{~mm}$. in 1 hour (Wintrobe). No biopsy was taken.

She was treated with heparin and prednisolone $15 \mathrm{mg}$. q.i.d. There was a remarkable response to this therapy, and though the anterior half of the tongue and part of

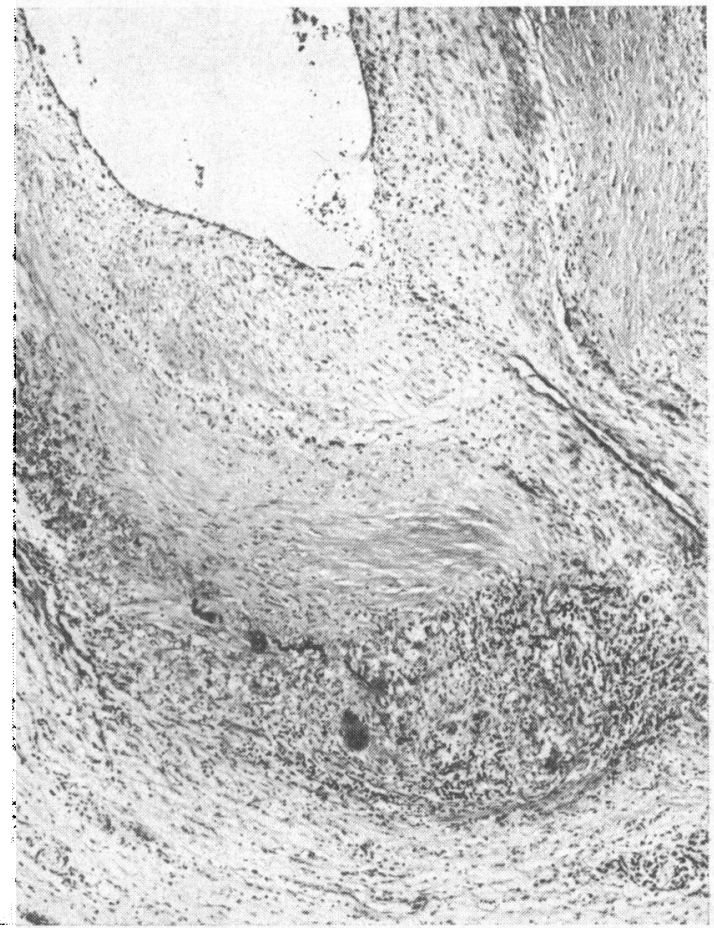

FIG. 2.-Case 1. Right coronary artery showing extreme fragmentation of the internal elastic lamina, chronic inflammatory cells and giant cells in the media, and intimal thickening. (Haematoxylin and eosin. $\times 65$.)

the lower lip and scalp became gangrenous and sloughed off, she made a good recovery. She returned home three months after admission, her dose of prednisolone having been reduced to $5 \mathrm{mg}$. b.d., with the recommendation that this should be continued for the next two years.

She remained well until 1967 when she was found collapsed at home. On admission to hospital she was semicomatose, there was a left hemiparesis, and her blood pressure was $130 / 80 \mathrm{~mm}$. Hg. There were hypertensive changes in the blood vessels of the optic fundi.

She died 3 days later without regaining consciousness.

Necropsy (Dr. B. J. Murray). A dissecting aneurysm was present in the ascending aorta, extending into the aortic arch and its branches; proximally it had ruptured into the pericardial sac which contained $100 \mathrm{ml}$. of blood clot. There was a transverse tear $(2 \mathrm{~cm}$. long) in the tunica intima $2.5 \mathrm{~cm}$. above the aortic valve ring.

The heart was enlarged (weight $601 \mathrm{~g}$.) due to left ventricular hypertrophy.

The only other relevant finding was a recent infarct in the right cerebral hemisphere.

Histology. The temporal arteries were not examined histologically, but sections from both lingual arteries and other small arteries in the neck showed characteristic 


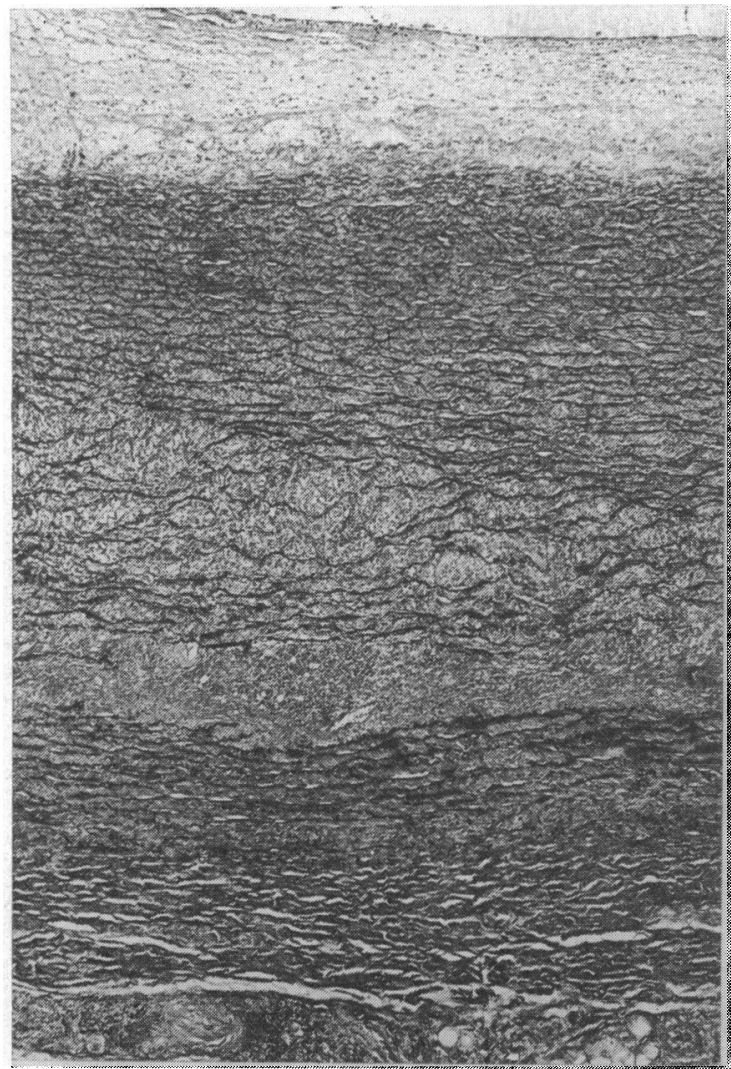

FIg. 3.-Case 1. Longitudinal section of aorta showing loss of elastic fibres and chronic inflammatory cell infiltration of the media. (Elastic van Gieson. $\quad \times 43$.) features of healed giant cell arteritis (Fig. 5). The tunica intima was greatly thickened by delicate fibroelastic tissue in which fibrocytes were plentiful. The internal elastic lamina was frayed and broken, and in some sections there was a new elastic lamina adjacent to the tiny lumen which remained. In the media there were occasional small foci of calcification and associated foreign body giant cells adjacent to the internal elastic lamina. In most arteries no other cellular infiltrate was present, but in one the tunica media and tunica adventitia were infiltrated by numerous lymphocytes, with a few multinucleated giant cells, not associated with calcification, in the media.

Five areas of the aorta were examined, and in all except one there was patchy infiltration of the tunica media by moderate numbers of lymphocytes and plasma cells but without any giant cells (Fig. 6). The inflammatory cells were most numerous in the outer third of the tunica media but in places extended through its whole thickness. There was extensive fragmentation of the elastic fibres of the tunica media, and several areas of fibrosis with complete loss of elastic tissue were present. Tolui-

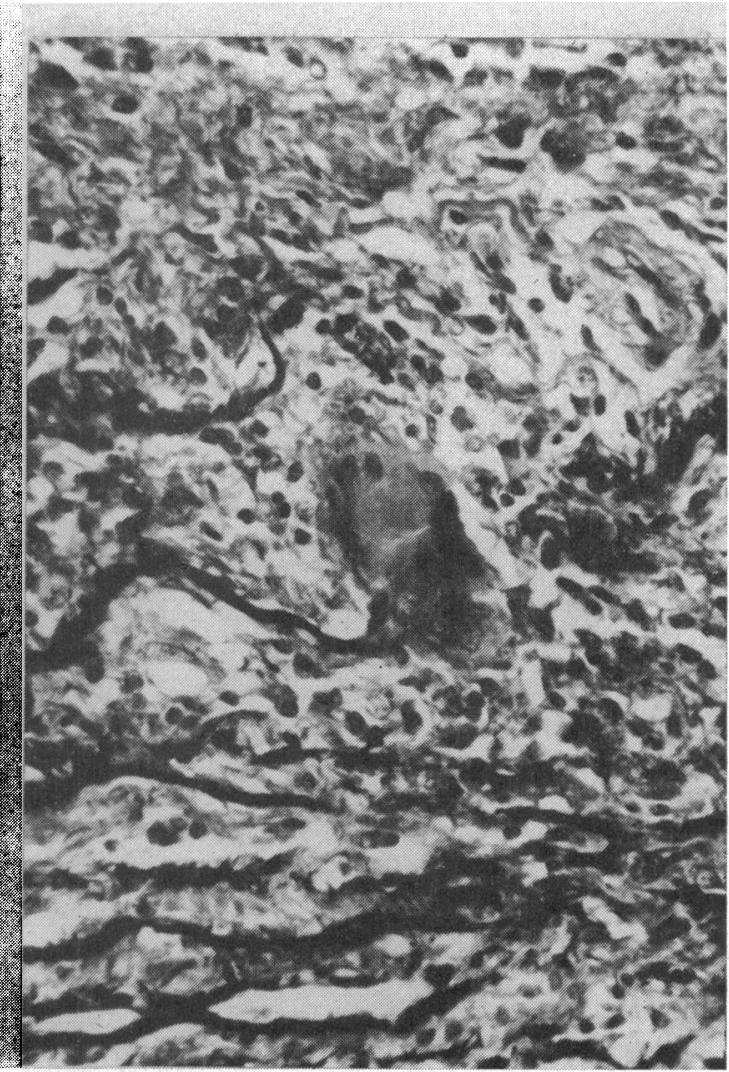

Fig. 4.-Case 1. Aorta showing giant cell and fragmented elastic fibres in the media. (Elastic van Gieson. $\quad \times 430$.) dine blue staining showed a considerable increase in metachromatic ground substance with formation of small "cysts", but this change was confined to the inner third of the tunica media and was not related to the inflammatory cell infiltrate or to the plane of the dissecting aneurysm which was in the outer half of the tunica media. There was no endarteritis of the vasa vasorum.

Sections of the carotid arteries showed loss and fragmentation of elastic fibres in the tunica media and small zones of fibrosis infiltrated by a few lymphocytes and histiocytes. Giant cells were not present. The intima overlying the zones of medial fibrosis was slightly thickened by delicate collagen, and there was slight perivascular lymphocytic infiltration but no other change in the adventitia.

In two sections of the carotid arteries there was considerable disorganization of the wall due to extensive fibrosis and calcification of the tunica media, with several foreign body giant cells and moderate numbers of lymphocytes around the calcified zones.

Sections of the kidney showed hypertensive arteriolar lesions. 


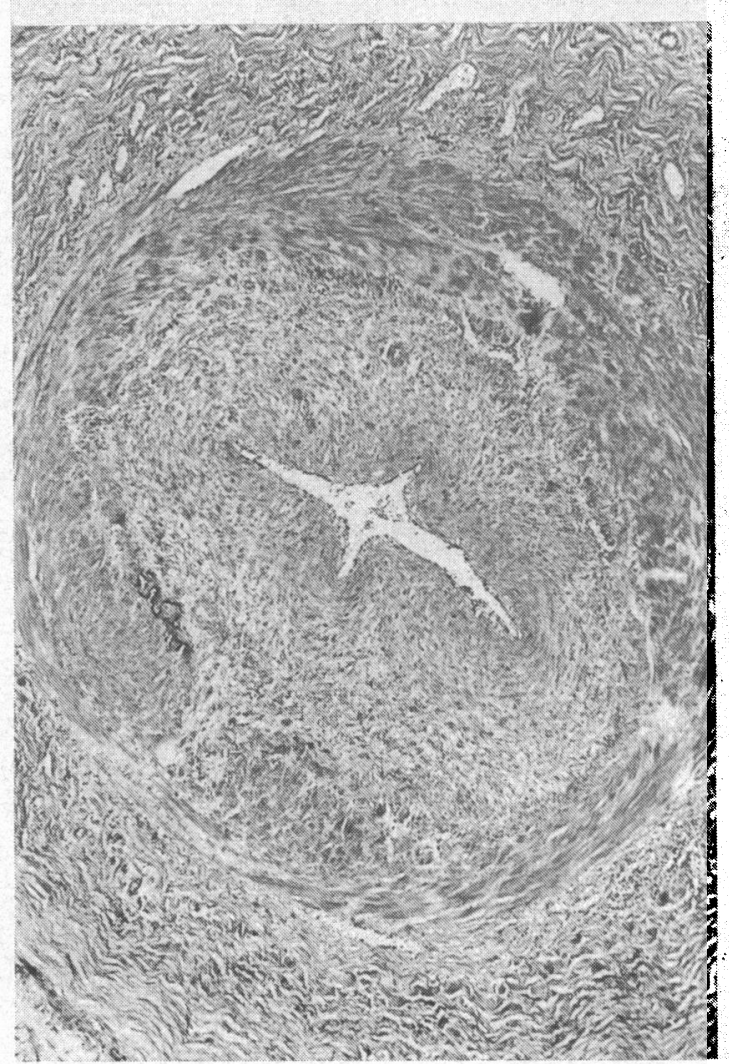

Fig. 5.-Case 2. Lingual artery. There is intimal thickening, and the internal elastic lamina is almost completely destroyed. (Elastic van Gieson. $\times 65$.)

\section{Discussion}

The two cases of dissecting aneurysm presented are both considered to be due to giant cell arteritis with aortic involvement. The possibility of syphilitic aortitis coexisting with giant cell arteritis elsewhere cannot be completely excluded, since serological tests for syphilis were not done; but the coincidence seems unlikely, particularly in the absence of endarteritis of the vasa vasorum. The histology of the tunica media of the aorta also resembles that in Takayasu's disease, but the absence of pronounced intimal fibrous thickening in the aorta, together with the age of the patients, is thought to exclude this diagnosis.

Giant cell arteritis involving many arteries including the aorta has been described by Cooke et al. (1946), Harrison (1948), and Cardell and Hanley (1951) amongst others, and it is now widely recognized that the disease process is often generalized.

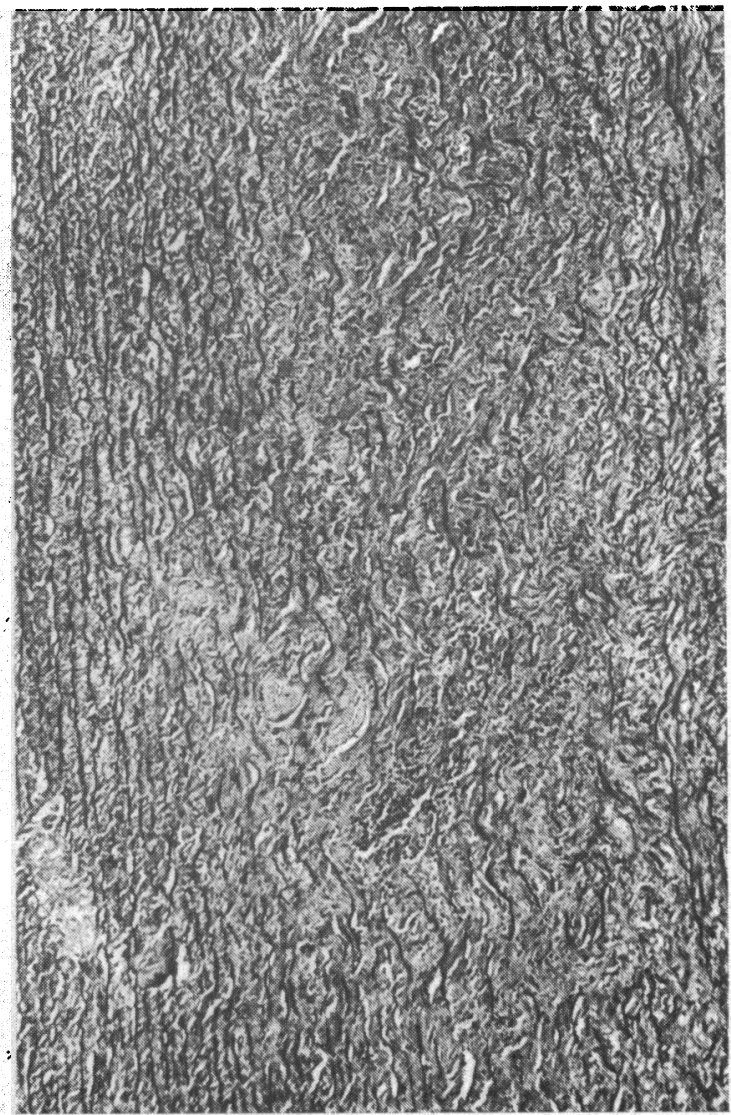

FIG. 6.-Case 2. Aortic media showing fragmentation of elastic laminae and moderate lymphocytic infiltration. (Elastic van Gieson. $\quad$ × 78.)

There are a small number of recorded cases of aneurysms of the aorta and large arteries associated with giant cell arteritis (e.g. Gilmour, 1941; Harrison, Harrison, and Kopelman, 1955; Reid, 1957), and even fewer have been reported in which dissecting aneurysm has been due to this disease. The 9 published examples are summarized in the Table, together with the 2 cases reported in this paper. In 2 of the cases tabulated (McMillan, 1950; Clinicopathological conference, 1960) the extent of the dissection was slight. The case reported by Paulley and Hughes (1960) was one of the 76 cases of giant cell arteritis in a clinical study; no necropsy was recorded.

Eleven cases are clearly too few for statistical analysis, but it appears likely that hypertension, which was present in 8 of the 11, may play a part in the pathogenesis as it does in dissecting aneurysm from other causes (Shennan, 1934; Hurley and Birrell, 1956). 
TABLE

MAIN FEATURES OF RECORDED CASES OF DISSECTING ANEURYSM DUE TO GIANT CELL ARTERITIS

\begin{tabular}{|c|c|c|c|c|c|c|c|}
\hline Author & $\begin{array}{l}\text { Age } \\
\text { (yr.) }\end{array}$ & Sex & $\begin{array}{c}\text { History of } \\
\text { temporal } \\
\text { arteritis }\end{array}$ & $\begin{array}{l}\text { Hyper- } \\
\text { tension }\end{array}$ & Site of aneurysm & $\begin{array}{c}\text { Metachromasia } \\
\text { of aortic } \\
\text { media }\end{array}$ & $\begin{array}{c}\text { Giant cell } \\
\text { arteritis in } \\
\text { small arteries }\end{array}$ \\
\hline Broch and Ytrehus (1947): & 68 & $\mathbf{F}$ & + & + & Ascending aorta & Not recorded & + \\
\hline McMillan (1950) & 58 & $M$ & - & + & Ascending aorta & $\begin{array}{l}\text { Cystic medio- } \\
\text { necrosis not } \\
\text { present }\end{array}$ & Not recorded \\
\hline $\begin{array}{l}\text { Magarey (1950) } \\
\text { Clinico-pathological conference }\end{array}$ & $\begin{array}{l}75 \\
70\end{array}$ & $\begin{array}{l}\mathbf{F} \\
\mathbf{M}\end{array}$ & $\overline{+}$ & $\overline{+}$ & $\begin{array}{l}\text { Ascending aorta } \\
\text { Ascending aorta }\end{array}$ & $\begin{array}{l}\text { Not recorded } \\
\text { Not recorded }\end{array}$ & $\begin{array}{c}\text { Not examined } \\
+\end{array}$ \\
\hline $\begin{array}{l}(1960) \\
\text { Paulley and Hughes (1960): } \\
\text { Case } 11\end{array}$ & 70 & $\mathbf{F}$ & + & + & $\begin{array}{l}\text { Aortic arch and } \\
\text { descending aorta }\end{array}$ & $\begin{array}{l}\text { Necropsy not } \\
\text { recorded }\end{array}$ & $\begin{array}{l}\text { Biopsy not } \\
\text { performed }\end{array}$ \\
\hline $\begin{array}{l}\text { Ainsworth and Gresham (1961): } \\
\text { Case } 1\end{array}$ & 83 & $\mathbf{M}$ & ? & - & Ascending aorta & Not recorded & Not examined \\
\hline Manley (1962): Case A 4 & 75 & $\mathbf{F}$ & - & - & Ascending aorta & $\begin{array}{l}\text { Moderate; no } \\
\text { cysts }\end{array}$ & Not recorded \\
\hline Case A 10 & 60 & $\mathbf{F}$ & $\begin{array}{l}\text { No history } \\
\text { available }\end{array}$ & + & Ascending aorta & $\begin{array}{l}\text { Marked; cysts } \\
\text { present }\end{array}$ & Not recorded \\
\hline $\begin{array}{l}\text { Kindermann (1965) } \\
\text { This paper: Case } 1\end{array}$ & $\begin{array}{l}70 \\
70\end{array}$ & $\begin{array}{l}\mathbf{F} \\
\mathbf{F}\end{array}$ & \pm & + & $\begin{array}{l}\text { Ascending aorta } \\
\text { Ascending aorta }\end{array}$ & $\begin{array}{l}\text { Not recorded } \\
\text { Very slight }\end{array}$ & $\begin{array}{l}+ \\
+\end{array}$ \\
\hline Case 2 & 83 & $\mathbf{F}$ & + & + & $\begin{array}{l}\text { Ascending aorta } \\
\text { and arch }\end{array}$ & $\begin{array}{l}\text { Marked; } \\
\text { small cysts }\end{array}$ & + \\
\hline
\end{tabular}

A further point arising from the Table is the frequent absence of a clinical history of temporal arteritis. In some instances this may have been due to unavoidable inadequacies in a history taken from a moribund patient, but this was not so in every case, and the potential value of examining small arteries, particularly from the head and neck, in all necropsies on patients with dissecting aneurysm is emphasized.

The occurrence of gangrene of the tongue in Case 2 is a rare complication of giant cell arteritis, but has been recorded previously (see Henderson, 1967). It is of interest in this patient that, in spite of steroid therapy for 19 months, there were still signs of active arteritis in the aorta and in occasional small arteries of the neck. Harrison et al. (1955) compared arterial biopsies in 2 patients with temporal arteritis before and after treatment with cortisone for 5 weeks and ACTH for 11 days, respectively. They found complete regression of the inflammatory cell infiltration after treatment, except for the presence of a few lymphocytes in the tunica adventitia in the case treated with ACTH; there was no change in the intimal thickening or medial scarring. The present case confirms the latter observation, but indicates that active inflammation may not be completely controlled even by prolonged steroid therapy.

\section{SUMMARY}

Two cases of giant cell arteritis complicated by dissecting aneurysm of the aorta are described and previously reported cases are reviewed.

I am indebted to Professor T. F. Hewer, Dr. A. C. Hunt, and Mr. A. Baskerville for their advice, and to Dr. A. E. Read, Dr. A. M. G. Campbell, and Dr. D. H. Davies for access to their clinical records.

\section{REFERENCES}

Ainsworth, R. W., and Gresham, G. A. (1961). Giant-cell aortitis with rupture of the aorta. F. Path. Bact., 82, 203.

Broch, O. J., and Ytrehus, $\varnothing$. (1947). Tre nye tilfelle av arteritis temporalis. Nord. Med., 34, 1111.

Cardell, B. S., and Hanley, T. (1951). A fatal case of giantcell or temporal arteritis. F. Path. Bact., 63, 587.

Clinico-pathological conference (1960). A case of temporal arteritis demonstrated at the Postgraduate Medical School of London. Brit. med. F., 2, 287.

Cooke, W. T., Cloake, P. C. P., Goven, A. D. T., and Colbeck, J. C. (1946). Temporal arteritis: a generalized vascular disease. Quart. F. Med., 39 (n.s. 15), 47.

Gilmour, J. R. (1941). Giant-cell chronic arteritis. F. Path. Bact., 53, 263.

Harrison, C. V. (1948). Giant-cell or temporal arteritis: a review. F. clin. Path., 1, 197.

Harrison, R. J., Harrison, C. V., and Kopelman, H. (1955). Giant-cell arteritis with aneurysms. Effects of hormone therapy. Brit. med. f., 2, 1593.

Henderson, A. H. (1967). Tongue pain with giant cell arteritis. Brit. med. F., 4, 337.

Heptinstall, R. H., Porter, K. A., and Barkley, H. (1954). Giant-cell (temporal) arteritis. f. Path. Bact., 67, 507.

Hurley, J. V., and Birrell, J. H. W. (1956). Dissecting aneurysm of the aorta: a clinico-pathological analysis of 106 cases. Aust. Ann. Med., 5, 5.

Kindermann, G. (1965). Arteriitis temporalis mit generalisierter Arteriitis und Ruptur eines Aortenaneurysmas. Med.Klin., 60, 1008.

McMillan, G. C. (1950). Diffuse granulomatous aortitis with giant cells, associated with partial rupture and dissection of the aorta. Arch. Path., 49, 63.

Magarey, F. R. (1950). Dissecting aneurysm due to giantcell aortitis. F. Path. Bact., 62, 445.

Manley, G. (1962). Dissecting aneurysm of the aorta. M.D. Thesis, University of Bristol.

Paulley, J. W., and Hughes, J. P. (1960). Giant-cell arteritis, or arteritis of the aged. Brit. med. F., 2, 1562.

Reid, J. V. O. (1957). Dilatation of the aorta due to granulomatous (giant-cell) aortitis. Brit. Heart f., 19, 206.

Sailer, S. (1942). Dissecting aneurysm of the aorta. Arch. Path., 33, 704.

Shennan, T. (1934). Dissecting Aneurysms. Spec. Rep. Ser. med. Res. Coun. (Lond.), No. 193. 